Marquette University

e-Publications@Marquette

Psychology Faculty Research and Publications

Psychology, Department of

$1-1-2016$

\title{
Seven Reasons to Invest in Well-Being
}

Kathryn H. Howell

University of Memphis

John K. Coffey

Sewanee: University of the South

Gregory M. Fosco

Marquette University, Gregory.Fosco@Marquette.edu

Kristen Kracke

United States Department of Justice

Katherine S. Nelson

Sewanee: University of the South

See next page for additional authors

Accepted version. Psychology of Violence, Vol. 6, No. 1 (January 2016): 8-14. DOI. (C) 2016 American Psychological Association. Used with permission. 
Authors

Kathryn H. Howell, John K. Coffey, Gregory M. Fosco, Kristen Kracke, Katherine S. Nelson, Emily F. Rothman, and John Grych 
Marquette University

e-Publications@Marquette

\section{Psychology Faculty Research and Publications/College of Arts and Sciences}

This paper is NOT THE PUBLISHED VERSION; but the author's final, peer-reviewed manuscript. The published version may be accessed by following the link in the citation below.

Psychology of Violence, Vol. 6, No. 1 (January 2018): 8-14. DOI. This article is (C American Psychological Association and permission has been granted for this version to appear in e-Publications@Marquette. American Psychological Association does not grant permission for this article to be further copied/distributed or hosted elsewhere without the express permission from American Psychological Association.

\section{Seven Reasons to Invest in Well-Being / COMMENTARY}

Kathryn H. Howell

Department of Psychology, University of Memphis;

John K. Coffey

Department of Psychology, Sewanee: The University of the South

Gregory M. Fosco

Human Development and Family Studies, The Pennsylvania State University

Kristen Kracke

United States Department of Justice, Washington, DC

S. Katherine Nelson

Department of Psychology, Sewanee: The University of the South

Emily F. Rothman

Department of Community Health Sciences, Boston University School of Public Health

John H. Grych

Department of Psychology, Marquette University

\section{Abstract}


Objective: This commentary reviews current conceptualizations of well-being, examines explana- tions for the lack of attention to well-being research, and provides justification for investing research time and funding into well-being studies. Opportunities for integrating factors related to well-being into prevention and intervention programs are also outlined. Key Points: Well-being may motivate people toward success, improve health and longevity, strengthen relationships, and boost the economy. Well-being can be enhanced in easy and inexpensive ways by incorporating facets of well-being into already-existing individual and systems-level intervention or prevention programs. Implications: Future research into this important construct should focus on objective means to assess and predict well-being, as well as strategies to enhance well-being across the life span. Investing more research time and financial resources into the study and promotion of well-being has the potential to lead to profound and enduring benefits to individuals, communities, and the larger society.

Keywords: happiness, intervention, investment, life satisfaction

Acknowledgement: The views expressed in this article are those of the authors and do not represent official positions or policies of the Department of Justice.

When the World Health Organization was founded, it defined health as "a state of complete physical, mental, and social well-being, and not merely the absence of disease or infirmity" (Constitution of the World Health Organization, 1946). Now, 70 years later, an overwhelming majority of social science research has focused on a narrow and inverted view of health: one that emphasizes illness. This prioritization of efforts to understand illness is exemplified by the U.S. Centers for Disease Control and Prevention stated mission as preventing disease and lessening the burden of injuries (U.S. Centers for Disease Control \& Prevention, 2015). Similarly, the National Institute of Mental Health (NIMH) describes its vision as seeking "to transform the understanding and treatment of mental illnesses through basic and clinical research, paving the way for prevention, recovery and cure" (National Institute of Mental Health, 2015). Although the study of mental illness is unquestionably important, this narrow focus provides an incomplete conceptualization of health that can only yield a limited means for understanding and promoting well-being and improving people's lives.

In this commentary, we argue that investing more time, energy, and money in the study and promotion of wellbeing could have profound and lasting benefits to society, including but not limited to the reduction of interpersonal violence. In the sections that follow, we define well-being, provide seven reasons why increased attention to well-being would be beneficial, discuss reasons why social scientists may not have paid close attention to well-being, and address how an emphasis on well-being could be integrated into prevention and intervention efforts.

\section{What Is Well-Being?}

In this commentary, we use the term "well-being" to refer to a state of positive mental health. It is a multidimensional construct; historically, experts have made a distinction between hedonic well-being (e.g., the pursuit of pleasure), and eudaimonic well-being (e.g., the pursuit of one's full potential; Ryan \& Deci, 2001). However, researchers who study well-being have operationalized it somewhat differently, including as psychological flourishing (Keyes, 2002), life satisfaction (Diener, Emmons, Larsen, \& Griffin, 1985), positive emotions (Fredrickson, 2013), subjective well-being (Diener, 1984), happiness (Lyubomirsky, Sheldon, \& Schkade, 2005), or finding meaning in life (Steger, Frazier, Oishi, \& Kaler, 2006). A comprehensive discussion of the nuanced definitions of well-being is beyond the scope of this commentary, but is available elsewhere (see Kashdan, Biswas-Diener, \& King, 2008). 
What is common to these conceptualizations is the view that well-being goes beyond simply not being sick-it means feeling whole, empowered, self-actualized, happy, satisfied with life, or otherwise like one is living life to its fullest. Although it's true that psychological disorders can reduce well-being, indicators of well-being and psychopathology are largely independent (e.g., Antaramian, Scott Huebner, Hills, \& Valois, 2010; Keyes, 2007). Most people do not suffer from a mental illness, but that does not necessarily mean they are happy, fulfilled, and satisfied with their lives. Conversely, many people have a psychological disorder or impairment but also live engaged, meaningful lives. For example, research on the Dual Factor model of mental health indicates that individuals who report high levels of well-being and high levels of psychological symptoms exhibit better functioning across a range of domains than people who either have similar levels of symptomatology but report lower well-being, or those who report low symptoms and low well-being. Thus, well-being appears to have effects on adjustment that are distinct from those attributable to psychological disorders (Antaramian et al., 2010).

Despite challenges in defining and assessing well-being, study of the relation between well-being and other health-related outcomes has been an important innovation in psychological research (Antaramian et al., 2010; Keyes, 2007). We have learned from longitudinal studies that people with greater well-being and more positive affect go on to have greater success in marriage, friendships, and work, earn higher incomes, experience better physical health, and are less likely to abuse substances (Lyubomirsky, King, \& Diener, 2005). Accumulating evidence suggests that these positive outcomes are not simply correlates of well-being; rather, well-being prospectively predicts higher success and achievement in an array of important life domains. However, despite the growing empirical basis for the value of increasing well-being, the study of its causes, consequences, and promotion is typically marginalized within psychological research. Therefore, in the next section, we provide seven central arguments for including a new focus on well-being among mental health research priorities.

\section{Reasons to Invest in Well-Being Research and Promotion}

\section{Well-Being Is a Natural Motivator}

People who are coping with illness often lack the energy or resources to focus on anything other than recovery. On the other hand, individuals who are not ill are naturally motivated to act in ways that improve their wellbeing; they will strive toward happiness and success (e.g., Lyubomirsky, King, \& Diener, 2005). Healthy people often seek to take on new challenges, learn new things, become more creative and productive, solve problems, and stick with health treatment or self-improvement plans (Fredrickson, 2013). The desire to better one's life and deepen one's understanding of the world is innate and universal. Interestingly, despite the intrinsic drive to become happier, many people have difficulty identifying what will actually make them happier and struggle to make decisions or take actions that will produce improvements in their well-being (Nelson, Kushlev, \& Lyubomirsky, 2014; Wilson \& Gilbert, 2005). Yet, when people successfully pursue well-being, the benefits are compounding. Research suggests that people who pursue well-being in one way (e.g., taking a class, joining a book club or volunteering) are likely to experience additional psychological benefits (e.g., making new friends or feeling a sense of purpose), which initiates an upward spiral of positivity (Fredrickson, 2013). Further, positive affect expands one's coping and problem-solving repertoires, which are critical for protecting health and wellbeing in the face of stress and adversity (Fredrickson \& Joiner, 2002). By capitalizing on the reinforcing nature of activities related to well-being, low-cost and popular health promotion interventions will likely be generated.

\section{Well-Being Improves Physical Health and Longevity}

Experiencing positive affect, finding meaning in life, and feeling satisfied with life are all associated with improvements in physical health and longevity (Boehm \& Kubzansky, 2012; Boehm, Winning, Segerstrom, \& Kubzansky, in press; Hill \& Turiano, 2014; Holt-Lunstad, Smith, \& Layton, 2010; Pressman \& Cohen, 2005). The mechanisms by which this occurs have not yet been explicated, but one recent meta-analytic review found that 
social connectedness decreased the risk for mortality, even after controlling for physical inactivity and obesity (Holt-Lunstad et al., 2010). Another mechanism through which well-being might impact physical health may be the increased use of preventive care. Recent research found that people who were more satisfied with their lives were more likely to use preventive health care services, such as obtaining a mammogram or prostate exam (Kim, Kubzansky, \& Smith, 2015). Thus, promoting well-being could be an economical way to boost health and lower health care costs (Maciosek, Coffield, Flottemesch, Edwards, \& Solberg, 2010). In sum, there is a compelling association between well-being, physical health, and longevity, but additional work is needed to explicate the mechanisms by which well-being improves physical health.

\section{Well-Being Is Good for the Economy}

Because of boosts to workplace functioning and academic performance, well-being has important implications for the economy. Growing research documents the impact of well-being on the workplace and the quality of one's work. Contrary to the popular perception that depression facilitates creative genius, experiencing positive emotions is associated with improvements in creativity (Isen, Daubman, \& Nowicki, 1987). In addition, happier employees demonstrate greater organizational citizenship behavior, better job performance, and less conflict on the job (for a review, see Lyubomirsky, Sheldon, \& Schkade, 2005). Finally, employees who are not experiencing mental illness, but have low to moderate levels of well-being, make up nearly half of the population and account for the most missed work days (e.g., Keyes, 2007).

Similar to workplace benefits, well-being is also associated with better educational outcomes. In a prospective longitudinal study of early adolescents, well-being was related to increases in GPA, above and beyond the effects of SES, and internalizing or externalizing problems (Suldo, Thalji, \& Ferron, 2011). This is particularly important given the centrality of GPA in predicting educational attainment (e.g., Véronneau, Hiatt Racer, Fosco, \& Dishion, 2014). Further, a longitudinal study of college students found that higher levels of well-being predicted higher levels of academic success, health, and life satisfaction (Coffey, Wray-Lake, Mashek, \& Branand, 2015). Taken together, well-being contributes to more engaged, efficient, and effective workplace employees and students, which in turn leads to important economic benefits (e.g., Belfield \& Levin, 2007; CutcherGershenfeld, 1991).

\section{Well-Being Promotes Positive Relationships}

Happier people typically have more satisfying friendships and more positive, stable marriages (Lyubomirsky, King, \& Diener, 2005). Well-being is also related to pro-social behavior, as people with higher well-being are more likely to help others (Isen \& Levin, 1972; Lyubomirsky, King, \& Diener, 2005). Further, parents with higher levels of well-being tend to use more positive and supportive parenting strategies (Nelson, Kushlev, \& Lyubomirsky, 2014). A reverse process is also true: healthy relationships enhance well-being, so identifying ways to set this cycle to "positive" instead of abusive or negative could have exponential benefits. These well-being benefits underscore the potential for well-being promotion efforts to reduce interpersonal violence, divorce, some forms of delinquency and crime, and other social problems that are rooted in unhealthy relationships.

\section{Well-Being Can Be Enhanced in Relatively Easy and Inexpensive Ways}

Unlike many interventions for mental illness, well-being promotion strategies offer a low-cost, practical alternative for providing a potentially wide-scale impact. Experimental and meta-analytic evidence indicates that well-being may be enhanced with "positive activities," such as expressing gratitude, envisioning a bright future, or being kind to others (Bolier et al., 2013; Lyubomirsky \& Layous, 2013; Sin \& Lyubomirsky, 2009). Such interventions capitalize on evidence that even small changes may have a relatively large impact on people's lives (e.g., Walton, 2014). Notably, these positive activities can be simple to implement, self-directed, and require little time (e.g., 30 seconds to express gratitude once a day, or 30 minutes a week to envision a bright future). Relative to the amount of time, money, and resources devoted to resolving mental illness, the resources needed to engage people in positive activities are relatively minimal. 


\section{Improving Well-Being May Catalyze the Success of Other Interventions}

Larger investments in well-being research could reveal how to improve many different kinds of health and behavior interventions. One potential direction may be to incorporate activities that increase well-being into prevention and intervention efforts targeting particular disorders as a way to accelerate the effects of these programs. Alternatively, rather than trying to address a variety of psychological disorders with discrete interventions, it might be more promising to target well-being as a "common factor" that has wide-ranging and cascading benefits. For example, from a business standpoint, it may be that increasing employees' sense of purpose or life satisfaction could decrease worker burnout and turnover. Further, increasing employee wellbeing could promote better quality of work, less illness and absence, and lower health care costs. In turn, lower employee absences and turnover, and higher satisfaction, may result in better productivity and profitability in the workplace (e.g., Keyes, 2007; Luthans, Avolio, Avey, \& Norman, 2007). As highlighted above, well-being may result in better health. Better health can translate to better quality and quantity of life, lower health care costs, and more active engagement in the workplace and community.

\section{Well-Being Interventions May Elicit a Population-Level Shift in Mental Health}

It may seem counterintuitive, but if a well-being intervention results in even a small improvement for those who participate, it could still be cost-effective and have large-scale value. Social scientists and funders may be tempted to dismiss interventions unless dramatic turnarounds in individuals' functioning are observed, but this would be a mistake. To illustrate why: imagine that 1 million people download a free well-being app aimed to enhance their ability to remain calm during conflicts. The majority (75\%) of those who download the app do not derive any benefit, and those who do derive benefit show only small gains (e.g., they are slightly less aggressive). Many people might view this intervention as a failure. However, the small improvement translates to 250,000 people reducing their aggression on what could be a daily or weekly basis. Further, developing an app could be relatively inexpensive compared with the costs of responding to 250,000 acts of aggression per week. Although the above example is hypothetical, a number of apps oriented toward mental health have been developed in recent years. For example, Headspace is a mindfulness and meditation app that may contribute to improvements in sleep, focus, and immune health. Apps are also available to track mood symptoms, emotional health, and general well-being (e.g., T2 Mood Tracker). Although the clinical utility of these apps is still being researched, they have the potential to be a component of more scalable programs given their accessibility and ease of use.

Improving individual's well-being, even to a small degree, could pay off with tremendous dividends given that well-being is related to better physical health, family connectedness, social support, work productivity, and less risky behavior (Lyubomirsky, King, \& Diener, 2005). Moreover, well-being is "contagious" in that people with high levels of well-being tend to enhance the well-being of their coworkers, family members, friends, and even their customers (Lyubomirsky, Sheldon, \& Schkade, 2005). In other words, it is worthwhile to invest in low-cost well-being promotions because even if there isn't a huge gain, small improvements have the potential to reduce large-scale problems, such as violence perpetration, substantially.

\section{Why Is There Hesitancy About Promoting Well-Being?}

We consider it important to discuss the possible drawbacks to investing in well-being research and promotion. Government funds are limited and choices about the investment of research and health promotion dollars can be contentious. Given the wide range of social problems requiring solutions, a taxpayer or legislator might reasonably argue that we lack resources to attempt to "make people happy." They might also argue that wellbeing is too hard to define to make investing in its promotion a meaningful goal. There have also been critics of research on happiness, with some going so far as to call it "pseudoscience" that is fueling the self-help or 
"happiness industry" (Morrall, 2008, p. 207), and that a relentless focus on optimism can have unintended negative consequences (Ehrenreich, 2009). Still others have quite reasonably pointed out that the long-term impact of well-being interventions have not been established, and some can be challenging and complicated to produce (see Diener, Lucas, \& Scollon, 2006).

Promoting well-being may not be a panacea, but our current health promotion efforts leave clear room for improvement. The nation's health objectives and progress toward achieving them are detailed in a decennial report called Healthy People (National Center for Health Statistics, 2012). The Healthy People 2010 report found that nearly a third of the nation's 733 trackable objectives for the 2000 to 2010 decade were not met; most notably, obesity rates increased across all age groups, the proportion of U.S. adults who were current cigarette smokers did not noticeably change, adult binge drinking and illicit drug use did not decrease, the homicide rate remained the same while the suicide rate increased, and health disparities did not improve (National Center for Health Statistics, 2012). How might we enhance existing prevention and intervention strategies so that they become more appealing, engage people more effectively, and change behavior more permanently? Perhaps addressing people's happiness, sense of purpose, and other dimensions of well-being may be one key ingredient for many of our less effective strategies.

\section{Integrating an Emphasis on Well-Being Into Prevention and Intervention}

Traditionally, evidence-based interventions have focused primarily on the prevention or reduction of problems (e.g., domestic violence) and have generally prioritized psychopathology outcomes. There are currently hundreds of intervention programs to assist with reducing behavioral disorders (e.g., Brinkmeyer \& Eyberg, 2003; Cohen, Berliner, \& Mannarino, 2010; Lieberman, Ippen, \& Van Horn, 2006). Although many of these interventions also intend to increase positive functioning, the primary focus throughout the treatment is the reduction of psychopathology, which does not necessarily result in the enhancement of well-being. For example, when intervening with children exposed to violence, standard treatments focus on reducing symptoms of traumatic stress and depression or decreasing psychosocial dysfunction (e.g., Stein et al., 2003). There are also interventions that focus on resilience following adversity and detailed descriptions of such programs are available in other commentaries included in this special issue. For example, Shaw and colleague's article "Beyond Resilience: Why We Need to Look at Systems Too" addresses how to conceptualize, study, and intervene around resilience from a systems-level. Although lessening pathology and enhancing resilience are important aims, it may be possible to help victims of violence by also focusing more broadly on well-being related factors to widen their skill sets and resources. Therefore, reshaping intervention and prevention efforts to reduce or prevent pathology while also independently enhancing subjective well-being has the potential to provide substantial benefit to those in need. Such a joint approach to interventions, in which pathology and well-being both receive attention, may confer significant benefit (Ruini, Belaise, Brombin, Caffo, \& Fava, 2006).

\section{Individual-Level Strategies for Enhancing Well-Being}

Research on effective methods for increasing well-being reveal that meaningful improvements may occur when individuals focus on using their personal strengths in new ways, identify and discuss the causality of life events deemed "good," and express gratitude to someone new (Seligman, Steen, Park, \& Peterson, 2005). A variety of related strategies can be incorporated into traditional interventions to enhance well-being. These strategies might require a low level of participant activity (e.g., reflection or meditation about what one is thankful or grateful for; Wood, Froh, \& Geraghty, 2010), a medium level of participant activity (e.g., writing down or verbally sharing things for which they are grateful; Wood, Froh, \& Geraghty, 2010), or a high level of activity (e.g., engaging in acts of kindness such as spending money on others as opposed to on oneself, and practicing grateful behaviors such as delivering a letter to someone to whom the participant wishes to express gratitude; Dunn, 
Aknin, \& Norton, 2008; Wood, Froh, \& Geraghty, 2010). For a closer examination of narrative writing, which is one individually oriented method that has consistently been shown to have an effect on mental and physical well-being, we refer you to the commentary included in this special issue by Taylor and colleagues, titled "Narrating Prevention: Promises and Pitfalls." In their commentary, the authors explore the health benefits and positive coping associated with narrative writing exercises.

\section{Systems-Level Strategies for Enhancing Well-Being}

Similar to intervention services provided to individuals, systems-level approaches historically have been designed to ameliorate problems, not to promote well-being. However, as theory and research on well-being evolve, policymakers, funders, and program developers have begun to broaden their scope to include assetbased approaches, prevention, and promotion. Some frameworks for incorporating key elements of well-being into already-established programs have emerged. Each framework addresses the concepts of asset-building and skill development while also attempting to prevent or reduce the manifestation of a social problem. For example, the Interagency Working Group on Youth Programs has drafted a framework called Pathways for Youth that outlines strategies to promote positive outcomes and reduce risk across developmental stages by focusing on health, safety and wellness. The U.S. Department of Justice, in partnership with the Centers for Disease Control, recently developed a Shared Framework for Reducing Youth Violence and Promoting WellBeing, which addresses principles of action necessary for preventing and reducing youth violence and creating safe, healthy and thriving youth, families and communities. These systems-level action principles call for embracing positive youth development and well-being to provide safe, stable and nurturing environments. Overall, the available frameworks propose that programs be developed to promote well-being for individuals according to their developmental stage (e.g., youth, adult) and setting (e.g., family, school, community). Included in this special issue, the commentary "The Importance of Involving Youth in Developing, Implementing, and Evaluating Violence Prevention" by Edwards and colleagues offers additional insight into the crucial role that youth play in generating these systems-level, school-based prevention programs. By incorporating youth in designing and delivering prevention content, the effectiveness of such programs may be enhanced.

Current frameworks also emphasize the importance of building skills and assets in areas of physical and mental health; learning/doing (educational and vocational); safety; opportunity, service learning; and relational connectedness that are incorporated via civic and youth engagement, peer and adult activities, and communication skill building (Butts, Bazemore, \& Meroe, 2010). More specifically, systems-level strategies might include workplace policies that encourage employees to meditate or exercise, educational standards that promote social-emotional learning, or municipal funding for projects that enrich neighborhood collectivity. These types of activities are low-cost and could be easily built into existing programs, policies, or institutional operations (Duncan, Coatsworth, \& Greenberg, 2009; Lyubomirsky \& Layous, 2013). For a more detailed review of systems-based strategies at the community level, see the commentary within this special issue by Schultz and colleagues titled "The Key Role of Community Connectedness in Healing From Trauma." The authors address culturally specific interventions and the importance of increasing capacity for community connectedness as a target in treatment efforts following adversity.

\section{Conclusion}

We argue that a shift in the emphasis of psychological research from pathology to well-being may have transformative effects on individuals and the communities in which they live. Investigating how well-being affects and is affected by other important aspects of health and functioning has the potential to pave the way toward more effective prevention and intervention programs, as well as improvements in relationship, 
academic, and employment contexts. We have offered many reasons to invest in well-being research and provide guidance regarding future research directions (see Table 1) for this important construct. By highlighting the value of promoting subjective well-being, it is our intention that researchers and investors alike will gravitate away from a primary focus on psychopathology and toward an interest in the factors that enhance well-being across the life span.

Table 1

Key Research Questions to Further the Science on Well-Being

\begin{tabular}{|c|c|c|}
\hline Research domain & Research goal & Value of research \\
\hline $\begin{array}{l}\text { Well-being } \\
\text { assessment }\end{array}$ & $\begin{array}{l}\text { Include measures of subjective well-being in studies that } \\
\text { focus on mental health outcomes. } \\
\text { Assess and test subjective well-being as a moderator of } \\
\text { treatment effects for different mental and physical } \\
\text { health outcomes. } \\
\text { Incorporate multiple informants into the assessment of } \\
\text { well-being. }\end{array}$ & $\begin{array}{l}\text { Measures of well-being are typically brief, easy to administer, and a } \\
\text { useful way to end a survey on a positive note. These measures } \\
\text { would be relevant for both basic science and intervention studies. } \\
\text { Evaluate the hypothesis that well-being can function as a } \\
\text { "supermoderator" that enhances the effects of a range of } \\
\text { treatments. } \\
\text { Research that incorporates other perspectives may provide insight } \\
\text { into well-being in different contexts or interpersonal influences } \\
\text { on well-being. Discrepancies in self- and other-report data may } \\
\text { also provide new and valuable information. }\end{array}$ \\
\hline $\begin{array}{l}\text { Well-being } \\
\text { prediction }\end{array}$ & $\begin{array}{l}\text { Identify common and unique predictors of subjective } \\
\text { well-being and psychopathology. } \\
\text { Examine causal processes by which individual, family, } \\
\text { and setting characteristics lead to increased subjective } \\
\text { well-being. }\end{array}$ & $\begin{array}{l}\text { The detection of these variables would open new avenues for } \\
\text { developing models of well-being. } \\
\text { The use of both longitudinal and experimental methods will } \\
\text { provide the most comprehensive evaluation of well-being. }\end{array}$ \\
\hline $\begin{array}{l}\text { Well-being } \\
\text { intervention }\end{array}$ & $\begin{array}{l}\text { Enhance existing intervention programs by adding } \\
\text { intervention content that specifically targets well-being. }\end{array}$ & $\begin{array}{l}\text { Including well-being content may add to the overall effectiveness of } \\
\text { an intervention, either by contributing additional benefit to } \\
\text { participants or by enhancing other intervention components. }\end{array}$ \\
\hline $\begin{array}{l}\text { Well-being across } \\
\text { the lifespan }\end{array}$ & $\begin{array}{l}\text { Evaluate the developmental progression of subjective } \\
\text { well-being, or developmental variations in subjective } \\
\text { well-being. }\end{array}$ & $\begin{array}{l}\text { Developmental research may identify common components across } \\
\text { age points as compared to aspects of well-being that are more } \\
\text { pronounced among certain age groups. }\end{array}$ \\
\hline
\end{tabular}

Key Research Questions to Further the Science on Well-Being 
Table 1 Key Research Questions to Further the Science on Well-Being

\begin{tabular}{|c|c|c|}
\hline Research domain & Research goal & Value of research \\
\hline $\begin{array}{l}\text { Well-being } \\
\text { assessment }\end{array}$ & $\begin{array}{l}\text { Include measures of subjective well- } \\
\text { being in studies that } \\
\text { focus on mental health outcomes. } \\
\text { Assess and test subjective well-being } \\
\text { as a moderator of } \\
\text { treatment effects for different mental } \\
\text { and physical } \\
\text { health outcomes. } \\
\text { Incorporate multiple informants into } \\
\text { the assessment of } \\
\text { well-being. }\end{array}$ & $\begin{array}{l}\text { Measures of well-being are typically brief, } \\
\text { easy to administer, and a } \\
\text { useful way to end a survey on a positive } \\
\text { note. These measures } \\
\text { would be relevant for both basic science and } \\
\text { intervention studies. } \\
\text { Evaluate the hypothesis that well-being can } \\
\text { function as a } \\
\text { "supermoderator" that enhances the effects } \\
\text { of a range of } \\
\text { treatments. } \\
\text { Research that incorporates other } \\
\text { perspectives may provide insight } \\
\text { into well-being in different contexts or } \\
\text { interpersonal influences } \\
\text { on well-being. Discrepancies in self- and } \\
\text { other-report data may } \\
\text { also provide new and valuable information. }\end{array}$ \\
\hline Well-being prediction & $\begin{array}{l}\text { Identify common and unique } \\
\text { predictors of subjective } \\
\text { well-being and psychopathology. } \\
\text { Examine causal processes by which } \\
\text { individual, family, } \\
\text { and setting characteristics lead to } \\
\text { increased subjective } \\
\text { well-being. }\end{array}$ & $\begin{array}{l}\text { The detection of these variables would open } \\
\text { new avenues for } \\
\text { developing models of well-being. } \\
\text { The use of both longitudinal and } \\
\text { experimental methods will provide } \\
\text { the most comprehensive evaluation of well- } \\
\text { being. }\end{array}$ \\
\hline $\begin{array}{l}\text { Well-being } \\
\text { intervention }\end{array}$ & $\begin{array}{l}\text { Enhance existing intervention } \\
\text { programs by adding } \\
\text { intervention content that specifically } \\
\text { targets well-being. }\end{array}$ & $\begin{array}{l}\text { Including well-being content may add to the } \\
\text { overall effectiveness of } \\
\text { an intervention, either by contributing } \\
\text { additional benefit to } \\
\text { participants or by enhancing other } \\
\text { intervention components. }\end{array}$ \\
\hline $\begin{array}{l}\text { Well-being across the } \\
\text { lifespan }\end{array}$ & $\begin{array}{l}\text { Evaluate the developmental } \\
\text { progression of subjective } \\
\text { well-being, or developmental } \\
\text { variations in subjective } \\
\text { well-being. }\end{array}$ & $\begin{array}{l}\text { Developmental research may identify } \\
\text { common components across } \\
\text { age points as compared to aspects of well- } \\
\text { being that are more } \\
\text { pronounced among certain age groups. }\end{array}$ \\
\hline
\end{tabular}




\section{References}

Antaramian, S. P., Scott Huebner, E., Hills, K. J., \& Valois, R. F. (2010). A dual-factor model of mental health: Toward a more comprehensive understanding of youth functioning. American Journal of Orthopsychiatry, 80, 462-472.

Belfield, C. R., \& Levin, H. M. (Eds.). (2007). The price we pay: Economic and social consequences of inadequate education. Washington, DC: Brookings Institution Press.

Boehm, J. K., \& Kubzansky, L. D. (2012). The heart's content: The association between positive psychological well-being and cardiovascular health. Psychological Bulletin, 138, 655-691. 10.1037/a0027448

Boehm, J. K., Winning, A., Segerstrom, S., \& Kubzansky, L. D. (in press). Variability modifies life satisfaction's association with morality risk in older adults. Psychological Science.

Bolier, L., Haverman, M., Westerhof, G. J., Riper, H., Smit, F., \& Bohlmeijer, E. (2013). Positive psychology interventions: A meta-analysis of randomized controlled studies. BMC Public Health, 13, 119-138. 10.1186/1471-2458-13-119

Brinkmeyer, M. Y., \& Eyberg, S. M. (2003). Parent-child interaction therapy for oppositional children. In A. E.Kazdin \& J. R.Weisz (Eds.), Evidenced-based psychotherapies for children and adolescents (pp. 204223). New York, NY: Guilford Press.

Butts, J. A., Bazemore, G., \& Meroe, A. S. (2010). Positive youth justice: Framing justice interventions using the concepts of positive youth development. Washington, DC: Coalition for Juvenile Justice.

Coffey, J. K., Wray-Lake, L., Mashek, D., \& Branand, B. (2015). A longitudinal examination of a multidimensional well-being model in college and community samples. Journal of Happiness Studies. Advance online publication.

Cohen, J. A., Berliner, L., \& Mannarino, A. (2010). Trauma focused CBT for children with co-occurring trauma and behavior problems. Child Abuse \& Neglect, 34, 215-224. 10.1016/j.chiabu.2009.12.003

Constitution of the World Health Organization. (1946). World Health Organization: Basic documents (45th ed.). Geneva, Switzerland: World Health Organization.

Cutcher-Gershenfeld, J. (1991). The impact on economic performance of a transformation in workplace relations. Industrial \& Labor Relations Review, 44, 241-260. 10.1177/001979399104400204

Diener, E. (1984). Subjective well-being. Psychological Bulletin, 95, 542-575. 10.1037/0033-2909.95.3.542

Diener, E., Emmons, R. A., Larsen, R. J., \& Griffin, S. (1985). The Satisfaction With Life Scale. Journal of Personality Assessment, 49, 71-75. 10.1207/s15327752jpa4901_13

Diener, E., Lucas, R. E., \& Scollon, C. N. (2006). Beyond the hedonic treadmill: Revising the adaptation theory of well-being. American Psychologist, 61, 305-314. 10.1037/0003-066X.61.4.305

Duncan, L. G., Coatsworth, J. D., \& Greenberg, M. T. (2009). A model of mindful parenting: Implications for parent-child relationships and prevention research. Clinical Child and Family Psychology Review, 12, 255-270. 10.1007/s10567-009-0046-3

Dunn, E. W., Aknin, L. B., \& Norton, M. I. (2008). Spending money on others promotes happiness. Science, 319, 1687-1688. 10.1126/science.1150952 
Ehrenreich, B. (2009). Bright-sided: How the relentless promotion of positive thinking has undermined America. New York, NY: Metropolitan Books.

Fredrickson, B. L. (2013). Positive emotions broaden and build. Advances in Experimental Social Psychology, 47, 1-53. 10.1016/B978-0-12-407236-7.00001-2

Fredrickson, B. L., \& Joiner, T. (2002). Positive emotions trigger upward spirals toward emotional well-being. Psychological Science, 13, 172-175. 10.1111/1467-9280.00431

Hill, P. L., \& Turiano, N. A. (2014). Purpose in life as a predictor of mortality across adulthood. Psychological Science, 25, 1482-1486. 10.1177/0956797614531799

Holt-Lunstad, J., Smith, T. B., \& Layton, J. B. (2010). Social relationships and mortality risk: A meta-analytic review. PLoS Medicine, 7, e1000316. 10.1371/journal.pmed.1000316

Isen, A. M., Daubman, K. A., \& Nowicki, G. P. (1987). Positive affect facilitates creative problem solving. Journal of Personality and Social Psychology, 52, 1122-1131. 10.1037/0022-3514.52.6.1122

Isen, A. M., \& Levin, P. F. (1972). Effect of feeling good on helping: Cookies and kindness. Journal of Personality and Social Psychology, 21, 384-388. 10.1037/h0032317

Kashdan, T. B., Biswas-Diener, R., \& King, L. A. (2008). Reconsidering happiness: The costs of distinguishing between hedonics and eudaimonia. The Journal of Positive Psychology, 3, 219-233. $10.1080 / 17439760802303044$

Keyes, C. L. M. (2002). The mental health continuum: From languishing to flourishing in life. Journal of Health and Social Behavior, 43, 207-222. 10.2307/3090197

Keyes, C. L. M. (2007). Promoting and protecting mental health as flourishing: A complementary strategy for improving national mental health. American Psychologist, 62, 95-108. 10.1037/0003-066X.62.2.95

Kim, E. S., Kubzansky, L. D., \& Smith, J. (2015). Life satisfaction and use of preventive health care services. Health Psychology, 34, 779-782. 10.1037/hea0000174

Lieberman, A. F., Ippen, C. G., \& Van Horn, P. (2006). Child-parent psychotherapy: 6-month follow-up of a randomized controlled trial. Journal of the American Academy of Child \& Adolescent Psychiatry, 45, 913918. 10.1097/01.chi.0000222784.03735.92

Luthans, F., Avolio, B. J., Avey, J. B., \& Norman, S. M. (2007). Positive psychological capital: Measurement and relationship with performance and satisfaction. Personnel Psychology, 60, 541-572. 10.1111/j.17446570.2007.00083.x

Lyubomirsky, S., King, L., \& Diener, E. (2005). The benefits of frequent positive affect: Does happiness lead to success?Psychological Bulletin, 131, 803-855.

Lyubomirsky, S., \& Layous, K. (2013). How do simple positive activities increase well-being?Current Directions in Psychological Science, 22, 57-62. 10.1177/0963721412469809

Lyubomirsky, S., Sheldon, K. M., \& Schkade, D. (2005). Pursuing happiness: The architecture of sustainable change. Review of General Psychology, 9, 111-131. 10.1037/1089-2680.9.2.111

Maciosek, M. V., Coffield, A. B., Flottemesch, T. J., Edwards, N. M., \& Solberg, L. I. (2010). Greater use of preventive services in U.S. health care could save lives at little or no cost. Health Affairs, 29, 1656-1660. 10.1377/hlthaff.2008.0701 
Morrall, P. (2008). The trouble with therapy: Sociology and psychotherapy (p. 207). New York, NY: Open University Press.

National Center for Health Statistics. (2012). Healthy People 2010: Final review. Hyattsville, MD: Author.

National Institute of Mental Health. (2015). About the National Institute of Mental Health. Retrieved June 25, 2015, from http://www.nimh.nih.gov/health/publications/about-nimh-new/index.shtml

Nelson, S. K., Kushlev, K., \& Lyubomirsky, S. (2014). The pains and pleasures of parenting: When, why, and how is parenthood associated with more or less well-being?Psychological Bulletin, 140, 846-895. $10.1037 / \mathrm{a} 0035444$

Pressman, S. D., \& Cohen, S. (2005). Does positive affect influence health?Psychological Bulletin, 131, 925-971.

Ruini, C., Belaise, C., Brombin, C., Caffo, E., \& Fava, G. A. (2006). Well-being therapy in school settings: A pilot study. Psychotherapy and Psychosomatics, 75, 331-336. 10.1159/000095438

Ryan, R. M., \& Deci, E. L. (2001). On happiness and human potentials: A review of research on hedonic and eudaimonic well-being. Annual Review of Psychology, 52, 141-166. 10.1146/annurev.psych.52.1.141

Seligman, M. E. P., Steen, T. A., Park, N., \& Peterson, C. (2005). Positive psychology progress: Empirical validation of interventions. American Psychologist, 60, 410-421. 10.1037/0003-066X.60.5.410

Sin, N. L., \& Lyubomirsky, S. (2009). Enhancing well-being and alleviating depressive symptoms with positive psychology interventions: A practice-friendly meta-analysis. Journal of Clinical Psychology, 65, 467-487. 10.1002/jclp.20593

Steger, M. F., Frazier, P., Oishi, S., \& Kaler, M. (2006). The meaning in life questionnaire: Assessing the presence of and search for meaning in life. Journal of Counseling Psychology, 53, 80-93. 10.1037/00220167.53.1.80

Stein, B. D., Jaycox, L. H., Kataoka, S. H., Wong, M., Tu, W., Elliott, M. N., \& Fink, A. (2003). A mental health intervention for schoolchildren exposed to violence: A randomized controlled trial. JAMA: Journal of the American Medical Association, 290, 603-611. 10.1001/jama.290.5.603

Suldo, S. M., Thalji, A., \& Ferron, J. (2011). Longitudinal academic outcomes predicted by early adolescents' subjective well-being, psychopathology, and mental health status yielded from a dual-factor model. The Journal of Positive Psychology, 6, 17-30. 10.1080/17439760.2010.536774

U.S. Centers for Disease Control and Prevention. (2015). Mission, role and pledge. Retrieved July 1, 2015, from http://www.cdc.gov/about/organization/mission.htm

Véronneau, M. H., Hiatt Racer, K. H., Fosco, G. M., \& Dishion, T. J. (2014). The contribution of adolescent effortful control to early adult educational attainment. Journal of Educational Psychology, 106, 730-743. $10.1037 / \mathrm{a} 0035831$

Walton, G. M. (2014). The new science of wise psychological interventions. Current Directions in Psychological Science, 23, 73-82. 10.1177/0963721413512856

Wilson, T. D., \& Gilbert, D. T. (2005). Affective forecasting knowing what to want. Current Directions in Psychological Science, 14, 131-134. 10.1111/j.0963-7214.2005.00355.x

Wood, A. M., Froh, J. J., \& Geraghty, A. W. A. (2010). Gratitude and well-being: A review and theoretical integration. Clinical Psychology Review, 30, 890-905. 10.1016/j.cpr.2010.03.005 
